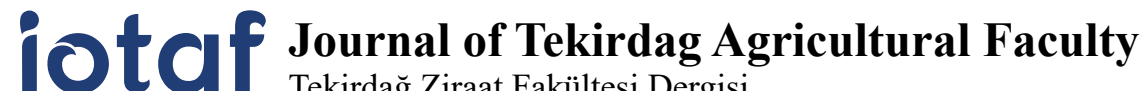 \\ Tekirdağ Ziraat Fakültesi Dergisi
}

Ocak/January 2019, 16(1) Basvuru/Received: 09/01/17 Kabul/Accepted: 07/04/17 DOI: $10.33462 /$ jotaf.288733

http://dergipark.gov.tr/jotaf http://jotaf.nku.edu.tr/

\section{Trans Yă̆ Asidi İçermez Beyanı Bulunan Bazı Endüstriyel Gıdaların Yağ Asidi Profilleri*}

\author{
Fatty Acid Profiles of Selected Industrial Foods with Zero Trans Fatty Acids Claim*
}

\author{
Bekir Alper DEMİR ${ }^{1}$, Murat TAŞAN ${ }^{1 * *}$
}

\section{$\ddot{O} z$}

$\mathrm{Bu}$ araştırmada, etiketlerinde "trans yağ asidi içermez" beyanı bulunan bazı gıda gruplarındaki trans yağ asit oranlarının Türk Gıda Kodeksi'nin gıda maddelerinin genel etiketleme ve beslenme yönünden etiketleme kuralları tebliğine göre uygunluğu incelenmiştir. Günümüz insan beslenmesinde önemi giderek artan trans izomerlerin yapısı, özellikleri, oluşumuna neden olan etkenler ve trans izomer oluşumunu önlemek için uygulanabilecek alternatif metotlar belirtilmiştir. Trans yağ asitlerinin ana kaynakları olarak gösterilen margarin grubuna ilave olarak yoğun olarak tüketilen ve içerisinde önemli düzeyde lipid şortening (endüstriyel yağlar) bulunan farklı gıda grupları oluşturulmuştur. Gıda grupları olarak kek ( 8 adet), bisküvi ( 8 adet), margarin ( 8 adet) ve cips ( 5 adet) olmak üzere 29 farklı markaya ait örnekler incelenmiştir. Kapiler gaz-sıvı kromatografisi (GLC) metodu ile belirlenen yağ asidi bileşimleri üzerinden değerlendirmeler yapılmıştır. Çalışmada trans oleik asit (C18:1), trans linoleik asit (C18:2) ve trans linolenik asit (C18:3) içerikleri belirlenmiştir. Elde edilen sonuçlara göre kek, bisküvi, margarin ve cips örneklerinde ortalama toplam trans yağ asidi oranları sırasıla; $\% 0,17-0,92 ; \% 0,11-0,46 ; \% 0,19-0,79$ ve \%0,26-1,21 arasında bulunmuştur. İncelenen örneklerden bir marka hariç diğer örneklerdeki toplam trans yağ asidi içeriklerinin ilgili tebliğdeki koşullara uygun olduğu tespit edilmiştir.

Anahtar Kelimeler: Trans yağ asitleri, etiketleme, kek, margarin, bisküvi, cips.

\begin{abstract}
In this study, labeled "trans fatty acid-free" declaration of trans fatty acids in the proportions of certain food groups of the Turkish Food Codex food labeling and nutrition labeling rules in terms of compliance were examined according to communigue. There were stated the trans isomers structures, specifications, factors to be formed and applicable alternative methods to prevent to come into being trans isomers which are getting increasing importance for human nutrition in nowadays. Several food groups which are frequently consuming and existing considerable lipid shortening (industrial fatty) were formed in additional to margarine groups which are shown as main source of trans fatty acids. Food groups as the cakes (8 pieces), biscuits (8 pieces), margarines ( 8 pieces) and chips ( 5 pieces) of the sample to be analyzed 29 different brands. Capillary gas-liquid chromatography (GLC) method for the assessment was made of the fatty acid composition. In the study, trans oleic acid (C18:1), trans linoleic acid (C18:2) and trans linolenic acid (C18:3) was determined. According to the results, total trans fatty acid contents were found in the cakes, biscuits, margarines and chips varies between $\% 0.17$ to $0.92 ; \% 0.11-0.46 ; \% 0.19-0.79$ and \%0.26-1.21. Except one of the examples in the samples examined, expect for trans fatty acid contents were verified to be appropriate in the circumstances notification.
\end{abstract}

Keywords: Trans fatty acids, labeling, cake, margarine, biscuit, chips.

\footnotetext{
1**Sorumlu Yazar/Corresponding Author: Murat Taşan, Namık Kemal Üniversitesi Ziraat Fakültesi Gıda Mühendisliği Bölümü. Süleymanpaşa, Tekirdağ. E-mail: mtasan@nku.edu.tr, (D) OrcID: 0000-0003-1490-7626 1Bekir Alper Demir, E-mail: balperdemir@hotmail.com, (D) OrcID: 0000-0001-7425-0326

Atıf/Citation: Demir, B.A., Taşan, M. Trans yağ asidi içermez beyanı bulunan bazı endüstriyel gıdaların yağ asidi profilleri. Tekirdağ Ziraat Fakültesi Dergisi, 16(1), 23-33.

*Bu çalışma Bekir Alper Demir'in yüksek lisans tezinden türetilmiştir.
} 


\section{Extendend Summary}

The Food and Drug Administration (FDA) ruled that, effective January 1, 2006, the nutrition labels for all conventional foods and supplements must indicate the content of trans fatty acids. This ruling represents the first substantive change to food labeling. This development has affected the food sector, especially the vegetable oil sector. In this regard the national vegetable oil sector in Turkey took very important measures. As a result, margarine and shortening contents of trans fatty acids has been very serious progress. In the national vegetable oil sector, there have been intense efforts to reduce the content of trans fatty acids by the influence of various legal and voluntary regulations and nutritional requirements. Many food industry companies in Turkey are working on new alternative options to produce trans fatty acid reduced foods. As a result of pressures to reduce or completely remove the amounts of trans fatty acids in food, food producers are hesitant to use the term hydrogenated oil in their food labels. Food manufacturers not only meet nutritional demands but also face the challenge of protecting the functional performance of non-trans products. In addition, The FDA issued a formal notice of industrially produced trans fats that no longer considered "generally safe" (GRAS) oils. With regard to food products contained trans fatty acids in Turkey, Turkish Food Codex "in terms of general labeling and nutrition labeling rules of foodstuffs" was organized in 2007 an amendment to the notification. In order not to include trans fatty acids in the statement table for nutrients, trans-fatty acid should be less than $1 \mathrm{~g}$ in $100 \mathrm{~g}$ of total fat in the product. Due to their natural structure, it was stated that conjugated polyunsaturated fatty acids would not be included in the calculation of the amount of trans fatty acids in foods containing meat, milk and their products. declaration of trans fatty acid content in food is compulsory in Turkey. This necessity is influential in the national food industry and especially in the vegetable oil sector. At the same time, the awareness of consumers or awareness of the consumers also requires new transformations in the food industry. The food industry is rapidly moving away from the partial hydrogenation technique which is the main source of trans fatty acids or changes the parameters of this technique. In addition, alternative techniques or new vegetable oil sources are used in the sector and used in production. In this study, labeled "trans fatty acid-free" declaration of trans fatty acids in the proportions of certain food groups of the Turkish Food Codex food labeling and nutrition labeling rules in terms of compliance were examined according to communigue. There were stated the trans isomers structures, specifications, factors to be formed and applicable alternative methods to prevent to come into being trans isomers which are getting increasing importance for human nutrition in nowadays. Several food groups which are frequently consuming and existing considerable lipid shortening (industrial fatty) were formed in additional to margarine groups which are shown as main source of trans fatty acids. Food groups as the cakes ( 8 pieces), biscuits ( 8 pieces), margarines ( 8 pieces) and chips ( 5 pieces) of the sample to be analyzed 29 different brands. In the selection of these food groups, large companies which are widely known and have national production and widespread distribution network are preferred. Margarine materials are in the package margarine. All materials were originally packaged. The materials are provided with three batch numbers for each brand, with different batch numbers from local markets. Capillary gas-liquid chromatography (GLC) method for the assessment was made of the fatty acid composition. In the study, trans oleic acid (C18:1), trans linoleic acid (C18:2) and trans linolenic acid (C18:3) was determined. According to the results, total trans fatty acid contents were found in the cakes, biscuits, margarines and chips varies between $\% 0.17$ to 0.92 ; $\% 0.11-0.46 ; \% 0.19-0.79$ and \%0.26-1.21. Except one of the examples in the samples examined, expect for trans fatty acid contents were verified to be appropriate in the circumstances notification. The results show that in the national vegetable oil sector, due to various legal and voluntary regulations and nutritional requirements, intensive efforts to reduce the content of trans fatty acids results. In addition, further studies are needed to solve various problems in product diversity and functional properties of the product. The optimization of fatty acid compounds in terms of saturated fatty acid (unsaturated fatty acid) / unsaturated fatty acid ratios is an important requirement. In our country, besides the rules for declaring the content of trans fatty acids in food labels, legal regulations which have the power to reduce the consumption of trans fatty acids and limit the content of trans fatty acids, especially in the case of Denmark, should be considered as the most effective option. 
İnsan vücudunun biyolojik gereksinimleri için diyetle alınması zorunlu olan besin öğelerinden yağlar, yaşamsal etkinliklerin gerektirdiği enerjiyi büyük ölçüde sağlamalarının yanı sıra, özellikle temel yağ asitlerini de içermeleri nedeniyle, diyetimizin vazgeçilmez unsurudur (Karaali, 1997). Diğer taraftan, fizyolojik olarak çok önemli olan yağların fazla alımı veya bazı yağ asitlerinin metabolizma üzerine olumsuz etkilere sahip olması nedeniyle alımının sınırlı düzeyde tutulması gerekmektedir. Yağların aşırı miktarlarda alımı obezite gibi hastalıklara neden olurken, özellikle trans yağ asitlerinin yüksek düzeylerde alınması koroner kalp hastalıklarına yakalanma riskini artırmaktadır. Tüketilen yağların doymuş ve doymamış yağ asidi içerikleriyle bunların kandaki kolesterol düzeyi üzerine etkileri bilinmektedir. Buna göre doymuş yağ asitleri kanda kolesterol düzeyinin yükselmesine neden olurken, doymamış yağ asitlerinin bu riski azalttığı belirlenmiştir. Son yapılan çalışmalara göre trans yağ asitleri de doymuş yağ asitlerinde olduğu gibi kolesterol düzeyini artırıcı etkiye sahip olduğu görülmüştür. Ayrıca trans yağ asitlerinin LDL kolesterol düzeyini artırmanın yanında HDL kolesterol düzeyini düşürdüğü ve LDL/HDL oranını da yükselttiğinden kardiyovasküler kalp hastalıkları riskini ciddi bir oranda artırmaktadır (Kayahan, 2003). Çalışmalar trans yağ asitlerinden elde edilen toplam enerjide \%2'lik bir artışın kalp krizi sonucunda ölüm riskinde \%23'lük bir artış ile ilişkili olduğunu göstermektedir (Mozaffarian ve ark., 2006, Brouwer ve ark., 2013). Aynı zamanda, trans yă̆ asitlerinin $\Delta$-6-desaturaz enzimini inhibe ederek, esansiyel yağ asitleri metabolizmasını etkilediği de belirtilmektedir. İlave olarak, trans yağ asitleri alımı ile bazı kanser türleri oluş dereceleri arasında önemli ilişkiler bulunduğu da bildirilmektedir (Innis ve ark., 1999). Trans yağ asitlerinin bazı araştırmalarda tip 2 diyabetlerini ilerlettiğine dair bir ilişki olduğu savunulmakta, çocuklarda ise alerji ve astım oluşumuna etkisi olduğu öne sürülmektedir (Taşan ve ark., 2007).

Trans yağ asitleri, insan beslenmesinde her zaman yer almıştır. Ruminant hayvanların rumenlerinde, doymamış yağ asitlerinin biyohidrojenasyonu sonucu doğal olarak az miktarlarda oluşmakta ve bu nedenle süt ve süt ürünleri ile diğer hayvansal yağlarda bulunmaktadır (Tavella ve ark., 2000, Martin ve ark., 2005). Diğer taraftan, bitkisel sıv1 yağların rafinasyonunda, deodorizasyon aşamasının özellikle sıcaklık ve süresine bağlı olarak, yağ asidi bileşimi etkilenmekte ve bu yağlarda az miktarlarda trans yağ asitleri oluşabilmektedir (Taşan ve Demirci, 2003, Taşan ve ark., 2005, Taşan ve Geçgel, 2008). Buna karşılık, trans yağ asidi içeriği yüksek yağların büyük çaplı ticari üretimleri, gelişen margarin endüstrisiyle başlamıştır. Çünkü margarin ve lipid şortening formülasyonlarında yer alan kısmi hidrojenize yağların üretimi süresince, doymamış yăg asitlerinin trans izomerleri meydana gelmektedir (Taşan ve Dağlığlu, 2005).

Yapısında margarin ya da hidrojenize bitkisel yağlar bulunan hazır gıdalar çeşitli toplumlarda fazlaca tüketilebilmektedir. Kısmi hidrojenize yağlar kek, bisküvi, kurabiye, mayonez, cips, milföy hamuru, pizza, gofret ve benzeri birçok ürünün üretiminde ve derin yağda kızartılmış fast-food tipi gıdaların hazırlanmasında kullanılmaktadır. Özellikle kısmi hidrojenasyon tekniği kullanılarak elde edilmiş yağları önemli miktarlarda içeren snack (tatlı, çerez vb.), fast-food ürünleri (cips, hamburger, pizza vb.) ve benzer diğer ürünler çocuklar ve gençler tarafından yüksek oranlarda tüketilmektedir (Enig ve ark., 1995). Bu nedenle endüstriyel kaynaklı trans yağ asidi alımı yüksek düzeylerde gerçekleşmektedir. Söz konusu bu gıdalardan endüstriyel kaynaklı trans yağ asidi alımının tamamen engellenmesi ve/veya belirli düzeyler altında tutulması önem arz etmektedir. Bu amacın sağlanabilmesi ancak öncelikle tüketilen gıdalardaki trans yağ asidi düzeylerinin belirlenmesi ile mümkün olabilmektedir (Zock ve Katan, 1997).

Gıda-Tarım Örgütü (FAO) ve Dünya Sağlık Örgütü (WHO) tarafından gıda proseslerinin trans yağ asidi oluşumunu azaltacak yönde uygulanması konusunda tavsiyeler yapılmaktadır. 2003 yılı FAO teknik raporunun 916.serisi, trans yağ tüketiminin mümkün olduğunca düşük (toplam enerji alımının \% 1'inden az) olması gerektiğini belirtmektedir. Dünya çapında trans yağlar konusunda bir politika uygulayan ilk ülke 2003 yılında Danimarka olmuştur. Bunun akabinde ise, İsviçre (2008), Avusturya (2009), İzlanda (2011), Macaristan (2014) ve Norveç'te (2014) aynı limitleri getiren yönetmelikler uygulamaya koymuştur (Anonim, 2015). Bunlarla birlikte, Avrupa Birliği'nde ise gıdalarda trans yağ asidi içeriği ile ilgili yasal bir düzenleme bulunmamaktadır. Kanada'da trans yağ asidi içeriğinin 0,2 g'dan daha fazla olması halinde etiket üzerinde porsiyon başına düşen gram şeklinde belirtilmesine yönelik göze çarpan etiketleme kanunu örneği mevcuttur (Anonim, 2014). Amerika Birleşik Devletleri (ABD), Gıda ve İlaç Kurumu (FDA), bütün gıda maddeleri etiketlerinde trans yağ asidi içeriğine ait bilgilerin bulundurulmasıyla ilgili kriterler belirlemiştir. Bu kriterler, etiket içeriğinde trans yağ asidi miktarının belirtilmesi zorunluluğunu 1 Ocak 2006'dan itibaren yasal olarak getirmiştir. Buna göre, ürünün porsiyonunda trans yağ asidi içeriğinin $0,5 \mathrm{~g}$ değerini aşması halinde ürün etiketinde ifade edilmesi zorunludur. $0,5 \mathrm{~g}$ değerinin altında olması halinde "trans yă asidi içermemektedir" terimi kullanılabilecektir. Bununla birlikte, endüstriyel olarak ve rumen hidrojenasyonu neticesinde oluşan trans yă̆ asidi arasında herhangi bir ayırım yapılmamaktadır (Taşan ve Geçgel, 2008). Ayrıca trans yağ asidi miktarının mümkün olduğunca düşük olmasının gerektiğini tüketicilere tavsiye etmektedir. Bu nedenle, pek çok gıda sanayi kuruluşu da trans yağ asidi miktarı düşürülmüş gıdaları üretmeye yönelik yeni alternatif seçenekler üzerinde çalışmaktadırlar (Bensadoun, 2003). Gıdalarda trans 
yağ asitleri miktarlarının azaltılması veya tamamen kaldırılması yönündeki baskılar neticesinde gıda üreticileri gıda etiketlerinde "hidrojenize yağ" terimini kullanmaktan dahi çekinmektedir. Gıda üreticileri sadece besinsel talepleri karşılama değil, aynı zamanda trans içermeyen ürünlerin fonksiyonel performanslarının (fiziksel, kimyasal ve tekstür vb. özellikler) korunması zorluklarıyla karşı karşıya kalmaktadır (Wassell ve Young, 2007).

WHO Avrupa Bölge Ofisi (Anonim, 2015) gıdalardaki trans yağ asidi içeriği sınırlandırılmadığından dolayı yüksek oranlarda trans yağ asidi içeren çok sayıda gıda ürününün hala Avrupa piyasasında bulunduğu belirtilmektedir. Üreticilerin gönüllü olarak yaptıkları düzenleme ile Avrupa Birliği’ndeki çoğu gıda ürününün her $100 \mathrm{~g}$ yağ için en fazla \%2 oranında trans yağ içerdiği, fakat bunun ülkeden ülkeye değiştiği ifade edilmektedir. Rapora göre, Avrupa Birliği ülkeleri arasında en yüksek trans yağ oranına sahip ülkeler Polonya, Bulgaristan, Slovenya, Hırvatistan ve İsveç olarak verilmektedir. Bununla birlikte, trans yağ asidi tüketiminin olumsuz etkilerine yönelik olarak kuvvetli kanıtlar ve artan toplumsal bilinç, Avrupa gıda üreticilerinin üzerindeki trans yağ asidini azaltmaya yönelik baskıyı arttırmıştır. Buna bağlı olarak, birçok ürün yeniden formüle edilerek trans yağ asidi içerikleri düşürülmüştür (Craig-Schmidt, 2006). FDA endüstriyel olarak üretilen trans yağların artık "genellikle güvenilir kabul edilen" (GRAS) yağlardan olmadığını belirleyen resmi bildirimi yayınlanmıştır. 18 Haziran 2018 için öngörüldüğ̈̈ şekilde bunun tamamen uygulamaya konulması halinde, bu durum endüstriyel olarak üretilen trans yağların onaylanmamış gıda katkısı konumunda olacağı ve bunları içeren ürünlerin yasal olarak satılamayacağı anlamına geldiği belirtilmektedir (FDA, 2013). Dolayısıyla ABD'de üreticilerin gıda ürünlerinde kısmi hidrojenize yağların kullanımına son vermeleri gerekecektir.

Ülkemizde içeriğinde trans yağ asitleri bulunan gıda ürünleri ile ilgili olarak, Türk Gıda Kodeksi "gıda maddelerinin genel etiketleme ve beslenme yönünden etiketleme kuralları" tebliğinde 2007 yılında yapılan değişiklikle (Tebliğ No: 40) bir takım düzenlemelere gidilmiş ve besin öğeleri ile ilgili beyan tablosunda "trans yağ asidi içermez" ifadesinin yer alabilmesi için trans yağ asidinin üründeki toplam yağın 100g'ında 1g'dan az olması koşulu getirilmiştir (Anonim, 2007). Ayrıca tebliğde doğal yapıları nedeniyle et, süt ve bunların ürünlerini içeren gıdalardaki trans yağ asidi miktarının hesaplanmasında konjuge çoklu doymamış yağ asitlerinin hesaba dâhil edilmeyeceği de ifade edilmiştir. Diğer taraftan, Gıda, Tarım ve Hayvancılık Bakanlığı Türk Gıda Kodeksi "Gıda Etiketleme ve Tüketicileri Bilgilendirme" yönetmeliğini (Anonim, 2017) yayımlayarak beslenme bildiriminin içeriğinde trans yağ asitleri konusunda ilave ve yeni bir düzenleme getirmiştir. Söz konusu düzenleme ilgili yönetmeliğin 35/1. maddesi ç bendinde "Diğer mevzuat hükümleri saklı kalmak kaydıyla; yağ, doymuş yağ, karbonhidrat, şekerler, protein ve tuz miktarları bilgilerine ilave olarak, sadece ilgili gıda kodeksinde tanımlanan sürülebilir yağ/margarinler, yoğun yağlar, bitkisel yağlar ve bu yağları içeren gıdaların \%2'den fazla trans yağ içermesi durumunda trans yağ miktarı bildirilir" şeklinde yer almaktadır. Ayrıca 31 Aralık 2019 tarihine kadar ilgili yönetmelik (Anonim 2017) hükümlerine uyulması zorunluluğu da getirilmiştir.

Ülkemizde 2007 yılından bu yana birçok üretici firma gönüllü olarak bu konuda etiket bilgilerinde düzenlemeye gitmekle birlikte ürünün toplam yağındaki trans yağ asidi oranını \%1'in altına indirdiklerini de "trans yoktur" ibaresiyle etiketlerinde beyan etmektedirler. Ülkemizdeki büyük margarin üreticilerinin dünyada en gelişmiş modifikasyon tekniklerini uygulamaları bu olumlu tabloyu ortaya çıkardığı belirtilmektedir. Diğer taraftan, WHO bulaşıcı olmayan hastalıkların önlenmesi ve kontrolü aksiyon planı (2013-2020) kapsamında üye ülkelere endüstriyel üretim ile oluşan trans yağ asitleri yerine doymamış yăg asidi oranı yüksek yağların kullanılması için gerekli tedbirlerin hayata geçirilmesi çağrısında bulunmaktadır. Uluslararası Gıda ve İçecek İttifakı (IFBA) üyeleri, tüketicilerin dengeli beslenmesine ve sağlıklı bir yaşam tarzını benimsemelerine yardımcı olmak amacıyla, ürünlerinde bulunan trans yağ asitleri miktarını aşamalı olarak azaltma taahhüdünde bulunmaktadır. IFBA üyeleri yaptıkları açıklamada, en geç 2018 yılı sonuna kadar dünya genelinde ürünlerinde bulunan trans yağ asidi miktarını 100 gramda 1 gramın altına indirmeyi taahhüt etmektedir (Anonim, 2016).

Bu çalışmada, etiketlerinde "trans yağ asidi içermez" beyanı bulunan bazı endüstriyel gıda gruplarındaki trans yağ asidi içeriklerinin Türk Gıda Kodeksi'nin "Gıda maddelerinin genel etiketleme ve beslenme yönünden etiketleme kuralları tebliğinde değişiklik yapılması hakkında tebliğ, No. 40" göre uygunluğu incelenmiştir. Ülkemizde gıda maddelerindeki trans yağ asidi içeriklerinin beyan zorunluluğu ulusal gıda endüstrisine ve özellikle de bitkisel yağ sektörüne etkili olmaktadır. Aynı zamanda tüketicilerin bilgilendirilmeleri veya bilinçlenmeleri de gıda endüstrisinde yeni dönüşümleri gerekli kılmaktadır. Gıda endüstrisi trans yağ asitlerinin başlıca kaynağı olan kısmi hidrojenizasyon tekniğinden hızla uzaklaşmakta veya bu tekniğin parametrelerini değiştirmektedir. Bunun yanında, alternatif teknikler veya yeni yağ kaynakları sektörde değerlendirilmekte ve üretimde kullanılmaktadır. $\mathrm{Bu}$ çalışma, son yasal düzenlemelerin gıda endüstrisine etkilerinin anlaşılmasında bir kesit sunmayı da amaçlamaktadır. 


\section{Materyal}

\section{Materyal ve Metot}

Materyal olarak, dört farklı endüstriyel gıda grubu seçilmiştir. Bu gruplar; margarin, kek, bisküvi ve cips şeklinde oluşturulmuştur. Bilindiği üzere, insan beslenmesinde trans yağ asitlerinin ana kaynakları endüstriyel olarak üretilen margarin ve lipid şortening grupları (endüstriyel yağlar) gösterilmekte ve ilgi bu gruplar üzerine odaklanmaktadır. Margarinler direkt olarak tüketiciye ulaşmasına rağmen lipid şorteningler genellikle çeşitli endüstriyel gıdaların formülasyonlarında yer alarak ulaşmaktadır. Materyal seçiminde önce "trans yağ asidi içermez" beyanı bulunan gıda grupları belirlenmiştir. Daha sonra seçilen margarin grubuna ilave olarak yoğun olarak tüketilen ve içerisinde önemli düzeyde lipid şortening bulunan yukarıda isimleri verilen 3 farklı gıda grubu daha oluşturulmuştur. Bu gıda gruplarına ait marka seçimlerinde ise, yaygın olarak bilinen, ulusal düzeyde üretim yapan ve yaygın dağıtım ağı bulunan büyük firmalar tercih edilmiştir. Buna göre, ifade edilen firmalara ait 8 farklı markalı margarin, 8 farklı markalı kek, 8 farklı markalı bisküvi ve 5 farklı markalı cips materyal olarak kullanılmıştır. Sonuçta toplam 29 farklı marka değerlendirmeye alınmıştır. Materyaller, analiz edilinceye kadar $+4^{\circ} \mathrm{C}$ 'de orijinal ambalajı ile muhafaza edilmiştir.

Margarin materyalleri paket margarin sınıfındadır. Tüm materyaller orijinal ambalajlı halde alınmıştır. Materyaller, lokal marketlerden farklı parti numaralarına sahip olacak şekilde, her bir marka için üç adet olmak üzere temin edilmiştir. Her bir marka kendi gıda grubu içerisinde kodlanmıştır (1, 2, 3... şeklinde).

\section{Metot}

Seçilen gıda maddelerinden yağların ekstraksiyonu

Gıda gruplarından kek, bisküvi ve cipslerin yağ ekstraksiyonları ICC (1982)'nin 136 nolu metodunda verilen koşullara göre gerçekleştirilmiştir. Margarin grubunda ise yağ fazı Torres ve ark. (2002)'ye göre ayrıştırılmıştır. $20 \mathrm{~g}$ örnek $50^{\circ} \mathrm{C}$ 'de 20 dakika süre içerisinde eritilerek santrifüj yardımı ile alınmıştır. Yağ fazı, susuz sodyum sülfat (NaSO4) ile kurutulmuştur. Yağ oranları gıda maddelerinin toplam ağırlığı üzerinden \% olarak ifade edilmiştir.

\section{Yağ asidi metil esterlerinin hazırlanması ve kapiler gaz-sıvı kromatografisine enjeksiyonu}

Ekstraksiyonla elde olunan yağ örnekleri AOCS (1992)'nin Ce 2-66 nolu metoda göre BF3-metanol ile yağ asidi metil esterlerine dönüştürülmüştür. Yağ asidi metil esterleri, Agilent 6890 Series kapiler gaz-sıv1 kromatografisinde (GLC) alev iyonizasyon detektörü (FID) ve Agilent 6890 Series kromatografi cihazında analiz edilmişstir.

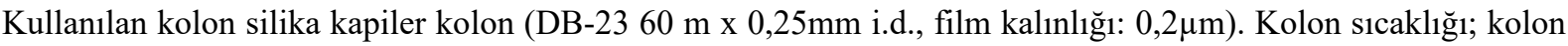
fırın programı ile 130oC'de 10 dakika bekletildikten sonra 5 kademelik artışla 180oC'ye, sonrasında 3 kademelik artışla 230oC'ye getirilerek bitirilmiştir. Enjeksiyon ve detektör sıcaklıkları 250, split oranı 1:100, enjeksiyon hacmi ise $1 \mu$ l'dır. Taşıyıcı gaz olarak da akış hızı $1 \mathrm{ml} / \mathrm{dk}$ olan helyum gazı kullanılmıştır. Yağ asidi metil esteri standartları Nu-Chek-Prep Inc.'den (Elysian, MN) temin edilmiştir.

\section{İstatistiksel analizler}

Elde edilen veriler her bir gida grubunda her bir marka için aritmetik ortalama halinde verildi. Elde edilen verilere tesadüfî blokları deneme desenine göre SPSS paket programı (SPSS Inc., Chicago, IL) kullanılarak varyans analizleri uygulandı. Önemli bulunan varyasyon kaynaklarına Duncan çoklu karşılaştırma testi uygulandı. Çizelgelerde ortalama veriler arasındaki farkın önem durumu harflendirme sistemi ile gösterildi.

\section{Bulgular ve Tartışma}

Bu çalışmada materyal olarak değerlendirilen dört farklı endüstriyel gıda grubuna ait yağ oranları, yağ asidi bileşimleri ve trans yağ asidi içerikleri belirlenmiş olup sonuçlar Çizelge 1, Çizelge 2, Çizelge 3 ve Çizelge 4'de verilmiştir. Örneklerde trans yağ asitlerine rastlanmış olup bu yağ asitleri toplam trans oleik asit (C18:1), toplam trans linoleik asit (C18:2), toplam trans linolenik asit (C18:3) olarak ifade edilmiştir. Bu asitlerin toplamı ise toplam trans yağ asitleri olarak belirtilmiştir. İlgili Çizelgelerde ayrıca trans yağ asitleri dışında belirli bazı doymuş ve doymamış yağ asitlerine de yer verilmiştir. Ancak sonuçlar ağırlıklı olarak trans asitleri üzerinden değerlendirilmiştir.

\section{Kek grubuna ait sonuçlar}

Çizelge 1'e bakıldığında, sekiz farklı markaya ait kek örneklerindeki toplam trans yağ asitleri \% 0,17 ile \% 0,92 arasında değiştiği görülmektedir. En yüksek toplam trans yağ asit miktarı 3 no'lu markaya ait kek örneğinde, en düşük toplam trans yağ asit miktarının ise 1 no'lu markaya ait kek örneğinde belirlendiği görülmektedir. Sekiz farklı markaya ait keklerdeki trans oleik asit (C18:1) değerinin \% 0,09-0,37 arasında değişmekte olup, incelenen tüm kek örneklerinde trans oleik asit (C18:1) varlığına rastlanılmıştır. Diğer taraftan, incelenen tüm kek örneklerinde ortalama yağ oranları \% 16,0-31,9 aralığında değişim göstermiştir. 
Çizelge 1. Kek örneklerin ortalama yağ oranları, yağ asidi bileşimleri ve trans yağ asidi içerikleri a

Table 1. The average fat content, fatty acid composition and trans fatty acid content in the cakes ${ }^{\text {a }}$

\begin{tabular}{ccccccccc}
\hline Yağ asitleri & \multicolumn{7}{c}{ Kek grubu marka kodlar1 } \\
\cline { 2 - 8 }$(\%)$ & 1 & 2 & 3 & 4 & 5 & 6 & 7 & 8 \\
\hline $\mathrm{C} 16: 0$ & $32,35 \mathrm{c}$ & $35,92 \mathrm{~cd}$ & $17,88 \mathrm{a}$ & $22,43 \mathrm{~b}$ & $35,33 \mathrm{~cd}$ & $39,74 \mathrm{~d}$ & $22,45 \mathrm{~b}$ & $23,52 \mathrm{~b}$ \\
\hline $\mathrm{C} 18: 0$ & $8,92 \mathrm{~d}$ & $7,56 \mathrm{c}$ & $5,62 \mathrm{a}$ & $6,65 \mathrm{~b}$ & 9,82 & $7,82 \mathrm{~cd}$ & $8,11 \mathrm{~d}$ & $5,49 \mathrm{a}$ \\
\hline $\mathrm{C} 18: 1$ & $26,89 \mathrm{~b}$ & $19,46 \mathrm{a}$ & $32,05 \mathrm{c}$ & $29,56 \mathrm{bc}$ & $38,43 \mathrm{~d}$ & $33,23 \mathrm{~cd}$ & $32,29 \mathrm{c}$ & $29,12 \mathrm{bc}$ \\
\hline$\Sigma \mathrm{C} 18: 1$ trans & $0,11 \mathrm{a}$ & $0,22 \mathrm{~b}$ & $0,12 \mathrm{a}$ & $0,12 \mathrm{a}$ & $0,09 \mathrm{a}$ & $0,10 \mathrm{a}$ & $0,24 \mathrm{~b}$ & $0,37 \mathrm{c}$ \\
\hline $\mathrm{C} 18: 2$ & 26,73 & 33,96 & 40,21 & 37,50 & 11,91 & 15,45 & 33,67 & 36,56 \\
\hline$\Sigma \mathrm{C} 18: 2$ trans & - & $0,19 \mathrm{c}$ & $0,80 \mathrm{~d}$ & $0,12 \mathrm{a}$ & $0,16 \mathrm{bc}$ & $0,14 \mathrm{ab}$ & $0,10 \mathrm{a}$ & $0,13 \mathrm{a}$ \\
\hline $\mathrm{C} 18: 3$ & $0,92 \mathrm{c}$ & $0,69 \mathrm{bc}$ & - & - & $0,12 \mathrm{a}$ & $0,26 \mathrm{a}$ & $0,34 \mathrm{ab}$ & $1,32 \mathrm{~d}$ \\
\hline$\Sigma \mathrm{C} 18: 3$ trans & $0,06 \mathrm{~b}$ & $0,02 \mathrm{a}$ & - & - & $0,03 \mathrm{a}$ & $0,02 \mathrm{a}$ & $0,03 \mathrm{a}$ & - \\
\hline Diğer yă̆ asitleri $\mathrm{b}$ & $4,02 \mathrm{~d}$ & $1,98 \mathrm{a}$ & $3,32 \mathrm{bc}$ & $3,62 \mathrm{~cd}$ & $4,11 \mathrm{~d}$ & $3,24 \mathrm{bc}$ & $2,77 \mathrm{~b}$ & $3,49 \mathrm{c}$ \\
\hline$\Sigma$ trans yă̆ asidi & $0,17 \mathrm{a}$ & $0,60 \mathrm{c}$ & $0,92 \mathrm{~d}$ & $0,24 \mathrm{a}$ & $0,28 \mathrm{ab}$ & $0,26 \mathrm{a}$ & $0,37 \mathrm{~b}$ & $0,50 \mathrm{c}$ \\
\hline Kek yağ içeriği $(\%)$ & $16,0 \mathrm{a}$ & $24,6 \mathrm{~cd}$ & $21,7 \mathrm{~b}$ & $27,2 \mathrm{~d}$ & $26,4 \mathrm{~d}$ & $27,1 \mathrm{~d}$ & $23,5 \mathrm{bc}$ & $31,9 \mathrm{e}$ \\
\hline
\end{tabular}

${ }^{a}$ Sonuçlar her bir marka için üç tekerrürün ortalaması olarak verildi. Yağ asitlerine ait değerler toplam yağ asitleri metil esterlerinin yüzdesi olarak verildi. Farklı harflerle gösterilen ortalamalar arasındaki fark istatistiksel açıdan önemli bulundu $(\mathrm{P}<0,01)$. Çizelgedeki istatistiksel farklılık değerlendirmesi yatay hizadaki harflendirmeler arasinda yapildi.

b $8,10,12,14,17,20,22,24$ karbonlu doymuş yağ asitleri ve 16, 17, 20, 22, 24 karbonlu-tek çift bağ 1 doymamış yağ asitleri toplamıdır.

Huang ve ark. (2006) çalışmalarında, keklerdeki toplam trans yağ asidi miktarlarını \% 0,51-1,77 arasında bulmuştur. En önemli trans yağ asidi türünün trans oleik asit (C18:1) olduğunu belirtmişlerdir. İncelediğimiz kek örneklerinde de en önemli trans yağ asidi türünün trans oleik asit (C18:1) olduğu belirlenmiştir. Geçmiş yıllarda (Dağlığlu ve ark., 2002), ülkemize ait keklerdeki trans yağ asidi miktarının \% 4,6 olduğu belirtilmiştir. Ülkemizde yapılan diğer bir çalışmada (Karabulut, 2007) ise 5 adet mini kek ve 4 adet kaplamalı kek örneği incelenmiş ve sonuç olarak mini keklerde toplam trans yağ asidi \% 2,40, kaplamalı keklerde ise \% 5,33 oranlarında belirlenmiştir. Başka bir çalışmada (Çağlav, 2008), keklerdeki toplam trans yağ asidi içeriğinin ortalama \%1,08 düzeyinde tespit edilmiştir. Çakmak ve ark. (2011) çalışmalarında keklerdeki toplam trans yağ asidi oranını \% 0-5,05 aralığında belirlemiş̧lerdir. Bu çalışmada ise keklerdeki toplam trans yağ asidi miktarının ortalama \% 0,42 olduğu belirlenmiştir. Literatürde yer alan sonuçlar incelendiğinde, hem dünyadaki hem de ülkemizdeki kek ürünlerinde toplam trans yağ asidi içeriğinin hızla düştüğü anlaşılmaktadır. Bilhassa literatürde 1970-1990 yılları ile 2000-2010 yıllar karşılaştırıldığında büyük farklılıklar ortaya çıkmaktadır. Diğer taraftan, Trattner ve ark. (2015), bu ürün kategorisinde doymuş yağ asidi oranlarında, bilhassa palmitik asit içeriklerinde, artışlar görüldüğünü vurgulamaktadırlar.

\section{Bisküvi grubuna ait sonuçlar}

Çizelge 2 incelendiğinde, sekiz farklı markaya ait bisküvi örneklerindeki toplam trans yağ asitlerinin \% 0,11-0,46 arasında değiştiği görülmektedir. En yüksek toplam trans yağ asit miktarı 3 no'lu markaya ait bisküvi örneğinde, en düşük toplam trans yağ asit miktarı ise 4 no'lu markaya ait bisküvi örneğinde belirlenmiştir. İncelenen tüm bisküvi örneklerinde trans linoleik asit (C18:2) belirlenmiş olup \% 0,01-0,40 aralığında değişim göstermiştir. Trans oleik asit (C18:1) 3 no'lu markaya ait bisküvi örneğinde tespit edilemez iken, diğer örneklerde ise \% 0,09-0,21 aralığında belirlenmiştir. Diğer taraftan, incelenen tüm bisküvi örneklerinde ortalama yağ oranları \% 14,8-29,1 aralığında değişim göstermiştir.

Çizelge 2. Bisküvi örneklerin ortalama yağ oranları, yağ asidi bileşimleri ve trans yağ asidi içerikleri a

Table 2. The average fat content, fatty acid composition and trans fatty acid content in the biscuits a

\begin{tabular}{|c|c|c|c|c|c|c|c|c|}
\hline \multirow{2}{*}{$\begin{array}{c}\text { Yağ asitleri } \\
(\%)\end{array}$} & \multicolumn{8}{|c|}{ Bisküvi grubu marka kodları } \\
\hline & 1 & 2 & 3 & 4 & 5 & 6 & 7 & 8 \\
\hline $\mathrm{C} 16: 0$ & $33,41 \mathrm{~d}$ & $30,56 \mathrm{~cd}$ & $27,89 \mathrm{bc}$ & $18,95 \mathrm{a}$ & $25,54 b$ & $16,05 \mathrm{a}$ & $42,52 \mathrm{e}$ & $35,20 \mathrm{~d}$ \\
\hline C18:0 & $7,09 \mathrm{~d}$ & $6,29 \mathrm{~cd}$ & $9,74 \mathrm{e}$ & $4,27 \mathrm{a}$ & $5,30 \mathrm{~b}$ & $5,26 b$ & $4,29 a$ & $6,01 b c$ \\
\hline
\end{tabular}


(Çizelge 2 devamı)

\begin{tabular}{ccccccccc}
\hline C18:1 & $32,26 \mathrm{de}$ & $36,80 \mathrm{ef}$ & $26,91 \mathrm{~b}$ & $19,21 \mathrm{a}$ & $27,61 \mathrm{~b}$ & $38,37 \mathrm{f}$ & $26,67 \mathrm{~b}$ & $26,34 \mathrm{~b}$ \\
\hline$\Sigma \mathrm{C} 18: 1$ trans & $0,11 \mathrm{a}$ & $0,14 \mathrm{~b}$ & - & $0,09 \mathrm{a}$ & $0,12 \mathrm{ab}$ & $0,19 \mathrm{~cd}$ & $0,18 \mathrm{c}$ & $0,21 \mathrm{~d}$ \\
\hline $\mathrm{C} 18: 2$ & $25,04 \mathrm{ab}$ & $23,92 \mathrm{a}$ & $30,78 \mathrm{bc}$ & $55,35 \mathrm{f}$ & $38,24 \mathrm{~d}$ & $35,57 \mathrm{~cd}$ & $21,31 \mathrm{a}$ & $30,27 \mathrm{~b}$ \\
\hline$\Sigma \mathrm{C} 18: 2$ trans & $0,07 \mathrm{c}$ & $0,03 \mathrm{a}$ & $0,40 \mathrm{c}$ & $0,01 \mathrm{a}$ & $0,02 \mathrm{a}$ & $0,03 \mathrm{a}$ & $0,10 \mathrm{~b}$ & $0,09 \mathrm{~b}$ \\
\hline $\mathrm{C} 18: 3$ & $0,22 \mathrm{~b}$ & $0,16 \mathrm{~b}$ & $0,07 \mathrm{a}$ & $0,33 \mathrm{c}$ & $0,67 \mathrm{~d}$ & $0,75 \mathrm{~d}$ & $0,27 \mathrm{bc}$ & $0,09 \mathrm{a}$ \\
\hline$\Sigma \mathrm{C} 18: 3$ trans & - & $0,05 \mathrm{~cd}$ & $0,06 \mathrm{~d}$ & $0,01 \mathrm{a}$ & $0,03 \mathrm{bc}$ & - & $0,01 \mathrm{a}$ & - \\
\hline Diğer yağ asitleri b & $1,80 \mathrm{a}$ & $2,05 \mathrm{ab}$ & $4,15 \mathrm{~cd}$ & $1,78 \mathrm{a}$ & $2,47 \mathrm{~b}$ & $3,78 \mathrm{c}$ & $4,65 \mathrm{~d}$ & $1,79 \mathrm{a}$ \\
\hline$\Sigma$ trans yağ asidi & $0,18 \mathrm{ab}$ & $0,22 \mathrm{bc}$ & $0,46 \mathrm{~d}$ & $0,11 \mathrm{a}$ & $0,17 \mathrm{ab}$ & $0,22 \mathrm{bc}$ & $0,29 \mathrm{c}$ & $0,30 \mathrm{c}$ \\
\hline Bisküvi yağ içeriği (\%) & $29,1 \mathrm{~d}$ & $26,4 \mathrm{c}$ & $21,1 \mathrm{~b}$ & $25,9 \mathrm{c}$ & $25,6 \mathrm{bc}$ & $15,2 \mathrm{a}$ & $14,8 \mathrm{a}$ & $20,6 \mathrm{~b}$ \\
\hline
\end{tabular}

a Sonuçlar her bir marka için üç tekerrürün ortalaması olarak verildi. Yăg asitlerine ait değerler toplam yăg asitleri metil esterlerinin yüzdesi olarak verildi. Farklı harflerle gösterilen ortalamalar arasındaki fark istatistiksel açıdan önemli bulundu $(\mathrm{P}<0,01)$. Çizelgedeki istatistiksel farklılık değerlendirmesi yatay hizadaki harflendirmeler arasında yapild1.

b $8,10,12,14,17,20,22,24$ karbonlu doymuş yağ asitleri ve 16, 17, 20, 22, 24 karbonlu-tek çift bağl1 doymamış yağ asitleri toplamıdır.

Sharp (2001), yirmi endüstriyel bisküvi örneğinde sadece bir markanın üretiminde hidrojene yağlar kullanıldığı ve sadece \% 6,5 oranında trans oleik asit içerdiğini belirtmiştir. İncelediğimiz bisküvi örneklerinde en önemli trans yağ asidi türünün trans oleik asit (C18:1) olduğu belirlenmiş olup ortalama \% 0,15 oranında trans oleik asit bulunmuştur. Dağlıŏlu ve ark. (2000) çalışmasında, ülkemizde üretilen bisküvilerin farklı oranlarda trans C18:1, trans C18:2 ve trans C18:3 içerdiklerini, bu farklılıkların bisküvi tipi, firma farklılığ ve en çok da üretimde farklı yağ asidi bileşimlerine sahip şorteninglerin kullanıldığını, bisküvi çeşitlerinin \% 1-30,5 oranında toplam trans yă̆ asidi içerdiği belirlenmiştir.

Brezilya kaynaklı kraker ve bisküvilerde (Martin ve ark., 2005) sırasıyla trans C18:1 \% 8,8-28,3; trans C18:2 $\%$ 0,0-0,15; trans C18:3 \% 0,0-0,75 arasında tespit edilmiştir. Huang ve ark. (2006) ise bisküviler de \% 0,511,77 aralığında trans yağ asidi bulmuştur. Kandhro ve ark. (2008), Pakistan bisküvilerinde \% 9,3-34,9 arasında yüksek miktarda toplam trans yağ asidi belirlemiştir. Yakın tarihlerde yapılan çalışmalarda ise, Kadığlu (2009) bisküvilerde trans oleik asit (18:1) oranlarını \% 0,68-3,11 aralığında belirlemiştir. Kala (2014), Hindistan'da üretilen bisküvilerde toplam trans yağ asidi miktarını \% 0,7-6,9 aralığında ve Santos ve ark. (2015), Portekiz kaynaklı bisküvilerde toplam trans yağ asidi miktarını \% 0,08-0,94 aralığında belirlemişlerdir. Bu çalışmada incelediğimiz sekiz farklı markalı bisküvi çeşidindeki ortalama toplam trans yağ asidi miktarının \% 0,24 olduğu tespit edilmiştir. Etiketlerinde "trans yağ içermez" ifadesi bulunan sekiz farklı bisküvideki toplam trans yăg asit miktarlarının \% 1'in altına düşürüldüğü ve firmaların beyan ettikleri değere uygun hareket ettikleri tespit edilmiştir. Kek ürünlerinde olduğu gibi, bisküvi ürünlerinde de hem dünya hem de ülkemiz literatürüne bakıldığında, trans yă̆ asidi içeriklerinin hızla düşürüldüğü görülmektedir. Bu ürünlerde kullanılan lipid şorteninglerin kısmi hidrojenasyon tekniğine alternatif tekniklerle üretilmesi trans yağ asitlerinin azaltılmasını sağlarken, bazı ürünlerde doymuş yağ asidi oranlarının da yüksek çıkmasına neden olmaktadır.

\section{Margarin grubuna ait sonuçlar}

Çizelge 3'te sekiz farklı markaya ait margarin örneklerindeki toplam trans yağ asidi miktarlarının \% 0,190,79 arasında değiştiği görülmektedir. En yüksek toplam trans yağ asit miktarı \% 0,79 ile 1 no'lu markaya ait margarin örneğinde belirlenmiştir. Margarin örneklerindeki trans oleik asit (C18:1) değerleri \% 0-0,37 arasında değişmektedir. Margarin markalarının yedisinde toplam trans oleik asit (C18:1) belirlenmiştir. Toplam trans linoleik asit (C18:2) miktarları ise \% 0-0,42 arasında değişmektedir. Margarin markalarının üçünde trans linolenik asit (C18:3) belirlenememiştir.

Çizelge 3. Margarin örneklerin ortalama yağ oranları, yağ asidi bileşimleri ve trans yağ asidi içerikleri a

Table 3. The average fat content, fatty acid composition and trans fatty acid content in the margarine ${ }^{a}$

\begin{tabular}{cccccccccc} 
Yağ asitleri & \multicolumn{8}{c}{ Margarin grubu marka kodlar1 } \\
\cline { 2 - 10 }$(\%)$ & 1 & 2 & 3 & 4 & 5 & 6 & 7 & 8 \\
\hline C16:0 & $35,56 \mathrm{~cd}$ & $37,95 \mathrm{~d}$ & $30,81 \mathrm{~b}$ & $24,22 \mathrm{a}$ & $39,22 \mathrm{de}$ & $41,25 \mathrm{f}$ & $32,97 \mathrm{bc}$ & $35,28 \mathrm{~cd}$ \\
\hline $\mathrm{C} 18: 0$ & $5,21 \mathrm{ab}$ & $6,43 \mathrm{~b}$ & $9,34 \mathrm{e}$ & $6,68 \mathrm{~b}$ & $7,49 \mathrm{~d}$ & $6,74 \mathrm{bc}$ & $4,22 \mathrm{a}$ & $4,78 \mathrm{a}$ \\
\hline
\end{tabular}


(Çizelge 3 devamı)

\begin{tabular}{ccccccccc}
\hline $\mathrm{C} 18: 1$ & $29,04 \mathrm{ab}$ & $31,87 \mathrm{~b}$ & $33,62 \mathrm{bc}$ & $33,31 \mathrm{~b}$ & $34,29 \mathrm{c}$ & $36,50 \mathrm{~d}$ & $37,52 \mathrm{~d}$ & $27,91 \mathrm{a}$ \\
\hline$\Sigma \mathrm{C} 18: 1$ trans & $0,37 \mathrm{~d}$ & - & $0,13 \mathrm{ab}$ & $0,10 \mathrm{a}$ & $0,10 \mathrm{a}$ & $0,20 \mathrm{c}$ & $0,09 \mathrm{a}$ & $0,15 \mathrm{~b}$ \\
\hline $\mathrm{C} 18: 2$ & $14,79 \mathrm{c}$ & $13,15 \mathrm{~b}$ & $16,36 \mathrm{~d}$ & $12,82 \mathrm{~b}$ & $12,82 \mathrm{~b}$ & $9,27 \mathrm{a}$ & $13,32 \mathrm{bc}$ & $17,42 \mathrm{~d}$ \\
\hline$\Sigma \mathrm{C} 18: 2$ trans & $0,42 \mathrm{~d}$ & $0,19 \mathrm{a}$ & $0,30 \mathrm{~b}$ & $0,35 \mathrm{c}$ & $0,35 \mathrm{c}$ & $0,32 \mathrm{bc}$ & - & $0,26 \mathrm{ab}$ \\
\hline $\mathrm{C} 18: 3$ & $0,45 \mathrm{~b}$ & $0,76 \mathrm{c}$ & $0,33 \mathrm{ab}$ & $0,97 \mathrm{~d}$ & $0,97 \mathrm{~d}$ & $0,21 \mathrm{a}$ & $1,39 \mathrm{e}$ & $0,55 \mathrm{~b}$ \\
\hline$\Sigma \mathrm{C} 18: 3$ trans & - & - & $0,12 \mathrm{bc}$ & $0,09 \mathrm{ab}$ & $0,09 \mathrm{ab}$ & $0,05 \mathrm{a}$ & $0,17 \mathrm{c}$ & - \\
\hline Diğgr yağ asitleri b & $14,16 \mathrm{c}$ & $9,65 \mathrm{~b}$ & $8,99 \mathrm{~b}$ & $4,67 \mathrm{a}$ & $4,67 \mathrm{a}$ & $5,46 \mathrm{a}$ & $10,32 \mathrm{~b}$ & $13,65 \mathrm{c}$ \\
\hline$\Sigma$ trans yağ asidi & $0,79 \mathrm{c}$ & $0,19 \mathrm{a}$ & $0,55 \mathrm{~b}$ & $0,54 \mathrm{~b}$ & $0,54 \mathrm{~b}$ & $0,57 \mathrm{~b}$ & $0,26 \mathrm{a}$ & $0,41 \mathrm{~b}$ \\
\hline Margarin yă̆ içeriği $(\%)$ & $80,3 \mathrm{c}$ & $42,8 \mathrm{a}$ & $60,8 \mathrm{~b}$ & $61,4 \mathrm{~b}$ & $61,4 \mathrm{~b}$ & $60,5 \mathrm{~b}$ & $62,2 \mathrm{~b}$ & $80,9 \mathrm{c}$
\end{tabular}

a Sonuçlar her bir marka için üç tekerrürün ortalaması olarak verildi. Yağ asitlerine ait değerler toplam yağ asitleri metil esterlerinin yüzdesi olarak verildi. Farklı harflerle gösterilen ortalamalar arasındaki fark istatistiksel açıdan önemli bulundu $(\mathrm{P}<0,01)$. Çizelgedeki istatistiksel farklılık değerlendirmesi yatay hizadaki harflendirmeler arasinda yapıldi.

b $8,10,12,14,17,20,22,24$ karbonlu doymuş yağ asitleri ve 16, 17, 20, 22, 24 karbonlu-tek çift bağl1 doymamış yağ asitleri toplamıdır.

Wagner ve ark. (2000) çalışmalarında margarinlerde trans yă̆ asidi oranın \% 1 'in altında olduğunu beyan edenlerde \% 0,3-0,8 ve diğer beyan etmeyenlerde \% 3,0-3,7 olduğunu belirlemiştir. Beninca ve ark. (2009) çalışmalarında, Brezilya kaynaklı margarinlerin \%13'ünde etiketleme düzenlemelerinin ihlal edildiği tespit edilmiştir. Bu çalışmada sekiz farklı üreticiye ait markalarda sonuçlara göre, üreticilerin etiketleme düzenlemelerine uygun hareket ettikleri ve toplam trans yağ asidi miktarının \% 1'in altına düşürüldüğü anlaşılmaktadır. Diğer taraftan, Gagliardi ve ark. (2009) çalışmalarında, trans yağ asidi içeriğinin düşürülmesine rağmen yüksek düzeyde doymuş yağ asidi (çoğunlukla palmitik asit) içerdiğini belirlemiştir. Toplam trans yağ asidi içeriklerini, Kroustallaki ve ark. (2011) margarinlerde \% 0,16-0,97 aralığında, Çıraklı (2011) paket ve kase margarinlerde \% 0-1,11 aralığında, Ergönül (2013) margarinlerde \% 1,1-2,2 aralığında belirlemişlerdir. Ülkemizde yapılan daha önceki benzer çalışmalara bakıldığında (Kayahan ve Tekin, 1994, Gündüç, 1995, Taş, 1998, Arıcı ve ark., 2002, Başol ve Taşan, 2008, Dabanoğlu, 2005, Karabulut ve Turan, 2006), geçmiş yıllarda margarinlerin toplam trans yağ asidi içeriklerinin çok daha yüksek oranlarda olduğu, trans yağ asitlerinin sağlıkla ilişkisini ortaya koyan araştırmalar, çeşitli sağlık kuruluşlarının tavsiyeleri ve yasal düzenlemeler sonucunda, dünyada yaşanan gelişmelere paralel olarak yakın zaman içerisinde bu oranın hızla düşürüldüğü anlaşılmaktadır. Aynı zamanda, ülkemizdeki etiketleme düzenlemesi trans yağ asitlerinin azaltılması veya kaldırılmasını teşvik eden bir rol oynamıştır. Diğer taraftan, Danimarka'daki trans yağ asidi yasal limitinin uygulanması örneği değerlendirildiğinde, trans yağ asitleri yerine doymuş yağ asitlerinin başlıca alternatif teşkil ettiği de görülmektedir. WHO Avrupa Bölge Ofisi (Anonim, 2015) raporunda, küçük ve orta ölçekli firmalar tarafından üretilen/kullanılan ve muhtemelen trans yağ asidi içeriği yüksek yağ kaynaklarının ambalajsız ürünlerin formülasyonlarında yer almasını azaltmada veya engellemede zorunlu etiketleme ve gönüllü reformülasyon uygulamalarının etkili olamayacağı ve düşük sosyoekonomik gruplar için bu durumun dezavantaja neden olacağı vurgulanmaktadır.

\section{Cips grubuna ait sonuçlar}

Çizelge 4 incelendiğinde, beş farklı markaya ait cips örneklerindeki toplam trans yağ miktarının \%0,26-1,21 arasında değiştiği görülmektedir. En yüksek toplam trans yă̆ asit miktarı 3 no'lu markaya ait cips örneğinde belirlenmiştir. En düşük toplam trans yağ asit miktarı 1 no'lu markaya ait cips örneğinde belirlenmiştir. Tüm markalara ait cips örneklerinde trans oleik asit (C18:1) belirlenirken, bu değer \%0,07-0,99 arasında değişmektedir. Benzer olarak, tüm markalara ait cips örneklerinde belirlenen trans linoleik asit (C18:2) değerleri \%0,15-0,27 aralığındadır.

Çizelge 4. Cips örneklerin ortalama yağ oranları, yağ asidi bileşimleri ve trans yağ asidi içerikleri a

Table 4. The average fat content, fatty acid composition and trans fatty acid content in the chips a

\begin{tabular}{cccccc}
\hline Yağ asitleri & \multicolumn{5}{c}{ Cips grubu marka kodları } \\
\cline { 2 - 6 }$(\%)$ & 1 & 2 & 3 & 4 & $39,12 \mathrm{c}$ \\
\hline $\mathrm{C} 16: 0$ & $39,76 \mathrm{c}$ & $29,08 \mathrm{a}$ & $41,19 \mathrm{c}$ & $35,43 \mathrm{~b}$ \\
\hline $\mathrm{C} 18: 0$ & $5,27 \mathrm{ab}$ & $4,76 \mathrm{a}$ & $5,89 \mathrm{bc}$ & $6,23 \mathrm{c}$ & $4,46 \mathrm{a}$ \\
\hline
\end{tabular}


(Çizelge 4 devami)

\begin{tabular}{cccccc}
\hline $\mathrm{C} 18: 1$ & $42,54 \mathrm{bc}$ & $47,92 \mathrm{~d}$ & $38,20 \mathrm{a}$ & $40,29 \mathrm{ab}$ & $44,78 \mathrm{~cd}$ \\
\hline$\Sigma \mathrm{C} 18: 1$ trans & $0,07 \mathrm{a}$ & $0,16 \mathrm{~b}$ & $0,99 \mathrm{~d}$ & $0,25 \mathrm{c}$ & $0,09 \mathrm{a}$ \\
\hline $\mathrm{C} 18: 2$ & $9,33 \mathrm{a}$ & $16,11 \mathrm{c}$ & $10,09 \mathrm{ab}$ & $12,36 \mathrm{~b}$ & $12,56 \mathrm{~b}$ \\
\hline$\Sigma \mathrm{C} 18: 2$ trans & $0,15 \mathrm{~b}$ & $0,27 \mathrm{c}$ & $0,17 \mathrm{~b}$ & $0,10 \mathrm{a}$ & $0,18 \mathrm{~b}$ \\
\hline $\mathrm{C} 18: 3$ & $0,43 \mathrm{~b}$ & $0,74 \mathrm{c}$ & $0,21 \mathrm{a}$ & $0,30 \mathrm{a}$ & $0,29 \mathrm{a}$ \\
\hline$\Sigma$ C18:3 trans & $0,04 \mathrm{a}$ & $0,03 \mathrm{a}$ & $0,05 \mathrm{a}$ & - & - \\
\hline Diğer yağ asitleri b & $2,41 \mathrm{~b}$ & $0,93 \mathrm{a}$ & $3,21 \mathrm{c}$ & $1,35 \mathrm{a}$ & $2,21 \mathrm{~b}$ \\
\hline$\Sigma$ trans yă̆ asidi & $0,26 \mathrm{a}$ & $0,46 \mathrm{~b}$ & $1,21 \mathrm{c}$ & $0,35 \mathrm{a}$ & $0,27 \mathrm{a}$ \\
\hline Cips yă̆ içeriği (\%) & $24,1 \mathrm{ab}$ & $31,6 \mathrm{c}$ & $20,3 \mathrm{a}$ & $28,4 \mathrm{bc}$ & $32,8 \mathrm{c}$ \\
\hline
\end{tabular}

a Sonuçlar her bir marka için üç tekerrürün ortalaması olarak verildi. Yağ asitlerine ait değerler toplam yağ asitleri metil esterlerinin yüzdesi olarak verildi. Farklı harflerle gösterilen ortalamalar arasındaki fark istatistiksel açıdan önemli bulundu $(\mathrm{P}<0,01)$. Çizelgedeki istatistiksel farklılık değerlendirmesi yatay hizadaki harflendirmeler arasında yapild1.

b $8,10,12,14,17,20,22,24$ karbonlu doymuş yağ asitleri ve 16, 17, 20, 22, 24 karbonlu-tek çift bağl1 doymamış yağ asitleri toplamıdır.

Aro ve ark. (1998) patates cipslerinde toplam trans yă̆ asidi düzeyini \% 0,67 olarak belirlenmiştir. Yiğit (2007) çalışmasında cipslerdeki toplam trans yağ asidi miktarını \%0,02-1,35 bulmuştur. Wijesundera ve ark. (2007), Avustralya'da kızartılmış patates cipslerinde trans yağ asidi değerinin yaklaşık \% 0,1-0,2 olduğunu belirtmiştir. Fernandez (2000) ise, patates cipslerindeki bu değeri \% 0,9 olarak belirlemiştir. Huang ve ark. (2006) çalışmalarında oldukça yüksek bir değer olarak patates cipslerindeki \% 6,39'u vermektedir. Benzer olarak, Semma (2002)'de Japonya'daki patates cipslerinde bu değeri \% 11 olarak bulmuştur. Yüksek değerler cipslerin üretiminde kullanılan yağların formülasyonlarında kısmi hidrojenize yağların olduğunu göstermektedir. Cipslerdeki trans oleik asit (C18:1) miktarının kaynağı büyük ihtimalle kısmi hidrojene tekniği ile üretilen yağlardır. Trans linoleik (C18:2) ve trans linolenik (C18:3) asitleri ise rafinasyon tekniği sırasında ve/veya cipslerin kızartılmaları sırasında uygulanan yüksek sicaklıklardan kaynaklanabilmektedir.

Çalışmada beş farklı markaya ait cips örneklerinde belirlenen ortalama toplam trans yağ asidi düzeyi \% 0,51 olup, incelediğimiz örneklerde bir markaya ait örneklerin ortalama değerleri (\% 1,2; 3 no'lu marka) hariç, toplam trans yağ asidi miktarının \%1'in altında olduğu anlaşılmaktadır. Verilen literatürlerden de anlaşıldığı üzere, cipslerdeki toplam trans içeriği geniş bir aralıkta değişmektedir. Ancak dünyada ve de ülkemizde çeşitli yasal veya gönüllü düzenlemelerin uygulanması ile bu değerlerin geçmişe nazaran düşüş gösterdiği de görülebilmektedir. Ulusal bitkisel yağ sektörümüzde margarin ve lipid şortening alt sektörü hem sahip olduğu son derece gelişmiş üretim teknolojileri hem de üretim kapasitesi ile önemli bir yere sahiptir. Dünya yağ sektöründe yaşanan gelişmelerin etkisiyle, Avrupa Birliği politikalarına paralel olarak margarin ve lipid şortening ürünlerinin içerikleri konusunda hızlı bir dönüşüm yaşanmaktadır.

\section{Sonuç}

$\mathrm{Bu}$ araştırmada, etiketlerinde "trans yağ asidi içermez" beyanı bulunan bazı gıda gruplarındaki trans yăg asit oranlarının Türk Gıda Kodeksi'nin gıda maddelerinin genel etiketleme ve beslenme yönünden etiketleme kuralları tebliğine göre uygunluğu incelenmiş olup, analiz edilen kek, bisküvi, margarin ve cips gida gruplarına ait örneklerde belirlenen yağ asidi bileşimi verilerine göre toplam trans yağ asidi oranları sırasıyla; \%0,17-0,92; $\% 0,11-0,46 ; \% 0,19-0,79$ ve \%0,26-1,21 arasında bulunmuştur. İncelenen örneklerden bir markaya ait örnekler hariç diğer örneklerdeki toplam trans yağ asidi içeriklerinin ilgili tebliğdeki koşullara uygun olduğu tespit edilmiştir. Elde edilen sonuçlar, ulusal bitkisel yağ sektöründe, çeşitli yasal ve gönüllü düzenlemelerin ve besinsel gereksinimlerin etkisiyle trans yağ asidi içeriklerinin azaltılmasına yönelik yoğun çabaların netice verdiğini göstermektedir. Bunlarla birlikte, ürün çeşitliliği ve ürünün fonksiyonel özellikleri konularında ortaya çıkan çeşitli sorunları çözmeye yönelik daha fazla çalışmanın yapılması, bilhassa sağlık gerekçeleri sebebiyle doymuş yağ asidi (palmitik asit)/doymamış yağ asidi oranları bakımından yağ asidi bileşimlerinin optimizasyonu önemli bir gerekliliktir. Ülkemizde, gıda etiketlerinde trans yă̆ asidi içeriğini beyan kuralları yanında, bilhassa Danimarka örneğinde olduğu gibi tüketicilerin trans yağ asidi tüketiminin azaltılması konusunda yaptırım gücü olan ve trans yağ asidi içeriğini kısıtlayıcı yasal düzenlemelerin en etkili seçenek olarak değerlendirilmesi gerekmektedir. 


\section{Kaynakça/References}

Anonim. (2007). Türk Gıda Kodeksi. Gıda maddelerinin genel etiketleme ve beslenme yönünden etiketleme kuralları tebliğinde değişiklik yapılması hakkında tebliğ (tebliğ no.40), 23.08.2007 ve 26622 sayılı Resmi Gazete, Ankara.

Anonim. (2014). Labelling of trans fatty acids. In: Canadian Food Inspection Agency. Ottawa: Government of Canada. www.inspection.gc.ca/ food/labelling (Erişim tarihi Ocak 2017).

Anonim, (2015). Avrupa'da trans yağların kaldırılması. Politika Özeti, Dünya Sağlık Örgütü (WHO) Avrupa Bölge Ofisi, Marmorvej, Cpenhagen, Danimarka. www.euro.who.int. (Erişim tarihi Ocak 2017).

Anonim, (2016). Avrupa Birliği’nde trans yağlar için limit belirlenmesi çağrısı. www.gidahatti.com (Erişim tarihi Ocak 2017)

Anonim, (2017). Türk Gıda Kodeksi. Gıda etiketleme ve tüketicileri bilgilendirme yönetmeliği, 26.12 .2017 ve 29960 sayılı Resmi Gazete, Ankara.

Arıcı, M., Taşan, M., Geçgel, Ü. \& Özsoy, S. (2002). Determination of fatty acid composition and total trans fatty acids of Turkish margarines by capillary Gas-Liquid Chromatography. Journal American Oil Chemists'Society, 79:439-441.

Aro, A., Amaral, HM., Kesteloot, H., Rimestad, A., Thamm, M. \& Van Poppel, G. (1998). TransFA in french fries, soups and snacks from 14 European Countries: The Transfair Study. Journal of Food Composition and Analysis, 11:170-177.

AOCS. (1992). Official Methods and Recommended Practices of the American Oil Chemists' Society, 4th Ed., American Oil Chemists'Society, Champaign, IL. Method.Ce.2-66.

Başol, B. \& Taşan, M. (2008). Fatty acid compositions of Turkish shortenings with emphasis on trans fatty acids. Journal of Food Lipids, 15:240-250.

Beninca, C., Zanoelo, FE., Luzjunior, LF. \& Spricigo, CB. (2009). Trans fatty acids in margarines marketed in Brazil: Content, labeling regulations and consumer information. European Journal Lipid Science Technology, 111:451-458.

Bensadoun, A. (2003). Trans Fatty Acids-health and labeling issues. Division of Nutritional Sciences, Cornell University. www.nutrition. cornell.edu/index.html. (Erişim tarihi Ocak 2017).

Brouwer, I.A., Wanders, A.J. \& Katan, M.B. (2013). Trans fatty acids and cardiovascular health: research completed? European Journal of Clinical Nutrition, 67(5):541-547.

Craig-Schmidt, M.C. (2006). World-wide consumption of trans fatty acids. Atherosclerosis Supplements, 7(2):1-4.

Çağlav, G. (2008). Marketlerde satılan keklerde trans yağ asitlerinin belirlenmesi. (Yüksek lisans tezi), Selçuk Üniversitesi Fen Bilimleri Enstitüsü, Konya.

Çakmak, YS., Gokalp, O., Yigit, S., Caglav, G. \& Aktumsek, A. (2011). Fatty acid composition and trans fatty acids in crisps and cakes in Turkey's markets. International Journal of Food Properties, 14(4):822-829.

Çıraklı, O. (2011). Ülkemizde üretilen bazı margarinlerin yă̆ asidi bileşiminin ve trans yağ asidi içeriklerinin belirlenmesi. (Yüksek lisans tezi), Namık Kemal Üniversitesi Fen Bilimleri Enstitüsü, Tekirdağ.

Dabanoğlu, S. (2005). Ülkemizde üretimi yapı̈lan çeşitli kahvaltılık ve sanayi tipi bitkisel margarinlerin bazı kimyasal ve fiziksel özelliklerinin araștırılması. (Yüksek lisans tezi), Ege Üniversitesi Fen Bilimleri Enstitüsü, İzmir.

Dağlıŏlu, O., Taşan, M. \& Tunçel, B. (2000). determination of fatty acid composition and total trans fa of Turkish biscuits by capillary gas liquid chromatography. European Food Research Technology, 211:41-44.

Dağlığlu, O., M. Taşan and B. Tunçel, 2002. Determination of FA composition and total trans FA in cereal based Turkish foods. Turkish Journal of Chemistry, 26:705-710.

Enig, MG., Pallansch, L.A., Sampugna, J. \& Keeney, M. (1995). Fatty acid composition of the fat in selected food items with emphasis on trans components. Journal American Oil Chemists'Society, 60:1781-1795.

Ergönül, P.G. (2013). Solid fat contents and instrumental textural attributes of margarines sold in Turkishmarket. Quality Assurance and Safety of Crops and Foods, 5(2):157-161

Fernandez, P.M. (2000). Fatty acid composition of commercial Spanish fast food and snack food. Journal of Food Composition and Analysis, $13: 275-281$

FDA. (2013). Food and Drug Administration. Final determination regarding partially hydrogenated oils; Federal Register, 80:34650-34670, www.gpo.gov (Erişim tarih Ocak 2017).

Gagliardi, A.C.M., Filho, J.M. \& Santos, R.D. (2009). Nutritional profile of foods with zero trans fatty acids claim. Rev Assos Med Bras. $55(1): 50-3$

Gündüç, N. (1995). Piyasadaki margarinlerin trans yă̆ asidi niceliği ve kan kolesterolü üzerine etkisi. (Yüksek lisans tezi), Ege Üniversitesi Fen Bilimleri Enstitüsü, İzmir.

Huang, Z., Wang, B. \& Pace, O.H. (2006). Trans fatty acid content of selected foods in an African-American community. Journal of Food Science, 7(6):322-327.

ICC. (1982). Standart Methods of the International Association for Cereal Chemistry Standard No:136, ICC, Detmold, Germany.

Innis, S.M., Green, T.J. \& Halsey, T.K. (1999). Variability in the trans fatty acid content of foods within a food category: Implications for estimation of dietary trans fatty acid in takes. Journal of the American College of Nutrition, 18(3):255-260.

Kadığlu, Y. (2009). Türkiye'de tüketilen bisküvi ve kek tipi ürünlerde kullanılan yağların bileşim, reolojik ve mikroskobik özellikleri. (Yüksek lisans tezi), Ankara Üniversitesi Fen Bilimleri Enstitüsü, Ankara. 
Kala, A.L.A. (2014). Studies on saturated and trans fatty acids composition of few commercial brands of biscuits sold in Indian market. Journal of Food Sci. Technol. 51(11):520-526.

Kandhro, A., Sherazi, S.T.H., Mahesar, S.A., Bhanger, M.I., Talpur, M.Y. \& Rain, S. (2008). Monitoring of fat content, free fatty acid and fatty acid profile including trans fat in Pakistani biscuits. Journal American Oil Chemists'Society, 85:1057-1061.

Karaali, A. (1997). Yemeklik yağlar ve sağlıkla ilişkileri. Glda Teknolojisi, 1(6):51-54.

Karabulut, S. \& Turan, S. (2006). Some Properties of margarines and shortenings marketed in Turkey. Journal of Food Composition and Analysis, 19:55-58.

Karabulut, İ. (2007). Fatty acid composition of frequently consumed foods in Turkey with special emphasis on trans fatty acids. International Journal of Food Sciences and Nutrition, 58(8):619-628.

Kayahan, M. (2003). Yağ Kimyasl, 1. Baskı, ODTÜ Yayıncılık, s.40, Ankara.

Kayahan, M. \& Tekin, A. (1994). Türkiye'de üretilen bazı margarinlerdeki trans yağ asitleri ve konjüge yağ asitleri miktarları üzerine araştırma. Glda Dergisi, 19(3):147-153.

Kroustallaki, P., Tsimpinos, G., Vardavas, C.I. \& Kafatos, A. (2011). Fatty acid composition of Greek margarines and their change in fatty acid content over the past decades. International Journal of Food Sciences and Nutrition, 62(7):685-691.

Martin, C.A, Carapelli, R., Visantainer, J.V., Matsushita, M. \& De Souzo, N.E. (2005). Trans fatty acid content of Brazilian biscuits. Food Chemistry, 93:445-448.

Mozaffarian, D., Katan, M.B., Ascherio, A., Stampfer, M.J. \& Willet, W.C. (2006). Trans fatty acids and cardiovascular disease. New England Journal of Medicine, 354(15):1601-1613.

Santos, L.A.T., Cruz, R. \& Casal, S. (2015). Trans fatty acids in commercial cookies and biscuits: An update of Portuguese market. Food Control, 47(2015):141-146.

Semma, M. (2002). Trans Fatty Acids: Properties, benefits and risks. Journal of Health Science, 48(1):7-13.

Sharp, T. (2001). Technical constraints in the development of reduced fat bakery products. Proceeding of the Nutritional Society, 60(4):489496.

Taş, G. (1998). Kahvaltıllk ve yemeklik margarinlerin genel ve trans yağ asitleri üzerine araştırma. (Yüksek lisans tezi), Hacettepe üniversitesi Fen Bilimleri Enstitüsü, Ankara.

Taşan, M. \& Demirci, M. (2003). Trans fatty acids in sunflower oil at different steps of refining. Journal of American Oil Chemists Society, $79: 825-828$

Taşan, M., Demirci, M. \& Geçgel, Ü. (2005). Bitkisel sıvı yağlarda trans yağ asitleri. Hasad Gıda, 21(242):31-35.

Taşan, M. \& Dağlığlu, O. (2005). Trans yağ asitlerinin yapısı, oluşumu ve gıdalarla alınması. Tekirdağ Ziraat Fakültesi Dergisi, 2(1):79-88.

Taşan, M., Kahyaoğlu, G. \& Demirci, M. (2007(. Beslenmemizde trans yağ asitlerinin kaynakları. Gıda Teknolojisi, 11 (7) $50-54$.

Taşan, M. \& Geçgel, Ü. (2008). Trans yağ asitleri ile ilgili yasal düzenlemeler ve yağ endüstrisine etkileri. TMMOB Kimya Mühendisleri Odası Güney Bölge Şubesi, Bitkisel Yemeklik Yağlar Sempozyumu, 82-86s, Adana.

Tavella, M., Peterson, G., Espeche, M., Cavallero, E., Cipolla, L., Luis, P. \& Caballero, B. (2000). Trans fatty acid content of seletion of foods in Argentina. Food Chemistry Analytical, 69:209-213.

Torres, D., Casal, S. \& Oliveria, M.B.P.P. (2002). Fatty acid composition of Portuguese spreadable fats with emphasing on trans isomer. European Food Technology, 214:108-111.

Trattner, S., Becker, W., Wretling, S., Öhrvik, V. \& Mattisson, I. (2015). Fatty acid composition of Swedish bakery products, with emphasis on trans-fatty acids. Food Chemistry, 175:423-430.

Wagner, K.H., Auer, E. \& Elmadfa, I. (2000). Content of trans fatty acids in margarines, plant oils, fried products and chocolate spreads in Austria. European Food Research Technology, 210:237-241.

Wassell, P. \& Young, N.W.G. (2007). Food applications of trans fatty acid substitues. International Journal Food Science and Technology, 42:503-517.

Wijesundera, C., Richards, A. \& Ceccato, C. (2007). Industrially produced trans fat in foods in Australia, 84:433-442.

Yiğit, Ş. (2007). Türkiye'de marketlerdeki cipslerdeki trans yağ asitlerinin belirlenmesi. (Yüksek lisans tezi), Selçuk Üniversitesi Fen Bilimleri Enstitüsü, Konya.

Zock, P.L. \& Katan, M.B. (1997). Butter, margarine and serum lipoproteins. Atherosclerosis, 131:7-16. 